\title{
Social Aspect of the Use of Modern Digital Technologies in the Protection of the Environment
} \author{
Konstantin Korolkov ${ }^{2 *}$ \\ ${ }^{1}$ Service Institute of Technology (branch) Don State technological University, Russia \\ ${ }^{2}$ North Caucasus Federal University, Russia \\ *Email: kur_er@bk.ru
}

Alexey Khabarov ${ }^{1}$, Ludmila Korol'kova ${ }^{1}$, Tatyana Chernavina ${ }^{1}$, Igor Shepet ${ }^{1}$,

\begin{abstract}
The article deals with the social aspect of the use of information technologies in the environmental protection. Environmental problems are currently quite acute, and structures that have a direct impact on the environment, for various reasons, are not always ready to implement systemic measures in this direction. In this regard, the importance of society's actions in the direction of solving environmental problems increases. The article provides a brief analysis of the level of perception of environmental problems by Russian society, and the willingness to be active in influencing social institutions in order to develop and implement a system of measures in the field of ecology. The conclusion is made, on the one hand, about the importance of this aspect, and on the other hand, about the lack of activity of the population in the direction of influencing social institutions in order to develop and implement a system of measures in the field of ecology. At the same time, the role of the young generation as a social group that responds most quickly and positively to the transmission of social information through the use of modern technologies, and thus has the most serious potential in the greening of society, is particularly noted. A number of recommendations are given to develop and deepen, with the help of information technologies, the perception of environmental problems by society and increase the activity of society in the direction of their solution.
\end{abstract}

Keywords: Ecology, Digital technologies, Information technology, Society, Youth, Consciousness.

\section{INTRODUCTION}

At the turn of the XX-XXI century, the problem of negative human impact on the environment has become more acute. The threat of major environmental catastrophes caused by ill-considered and unsystematic human activity and being a symmetrical response of nature to this activity has seriously increased.

It should also be noted the widespread introduction of modern information technologies in various areas of human activity. This is applied, in particular, to environmental protection.

Modern science carries out research on environmental protection in all areas of science and technology; it is the subject of activities of various organizations and at various levels. Under the influence of information technologies, our worldview is not only formed, but also strengthen the ability of society to transform social reality and the entire surrounding reality.

At the same time, the accumulation, classification and storage of information about the environment constantly accompany human activity. The main function of information systems is to provide information to the customer, which provides him/her with the required materials on a specific problem or issue in order to choose a better solution to the problem. The functioning of the information system involves the solution of a certain class of tasks, and provides a data warehouse, means for implementing various procedures, improving the quality of information provision. At the same time, the information provided by the information 
system is often in demand when solving problems of various kinds.

Modern re-equipment of production is based on high-tech technologies. In general, the purpose of information support for environmental research is to study and analyze the total amount of information, and to form effective mechanisms for decision-making and implementation at all levels of management of sociopolitical and economic processes based on the analysis of relevant material.

In search of an optimal solution to the entire complex of global problems, the world community, as is known, has developed a concept of sustainable development, which is closely related to the achievements of computer science and its role in the modern world [11]. The specialists in a particular order, as the concepts of the same level, along with the term "informatization" allocate "greening" - a process of sequential saturation, filling any possible environmental content that is a clear indication of the importance of the problem of environmental protection, as well as the possibility of active use of information technology $[9,10]$.

The 60-70s of the twentieth century were a time of awareness of the importance of global problems and the constitution of globalism as a special direction of scientific thought. This, in particular, was associated with the understanding of the specifics of the global ecology [1].

Nevertheless, traditional culture does not fully cope with the implementation of its adaptive function of harmonizing relations between society and nature, and the biosphere is at the limit of its compensatory capabilities under a powerful anthropogenic pressure [7]. Thus, the social aspect, which implies an appropriate perception of environmental problems by all members of society, is of great importance in protecting the environment

\section{METHODOLOGY OF THE PROBLEM OF USING MODERN TECHNOLOGIES IN ENVIRONMENTAL PROTECTION}

E.P. Semenyuk speaks about the process of greening the society and individual elements of the social structure. He considers the formation of social ecology to be the most significant moment in the evolution of eco-processes related to different spheres of logical knowledge in the twentieth century. It fully takes into account the social way of life of people and therefore is fundamentally a social discipline (in contrast to traditional ecology) [9].

The underlying reason for the emergence of social ecology and the gradual greening of society's life (both its consciousness and social practice) was the awareness in the second half of the twentieth century of the severity of the environmental crisis and its global scale. It is the difficulties of a resource-ecological nature that, as is known, form the central core of the global problems of our time.

Experts point to the greening of public consciousness in Russia. However, currently, according to VTsIOM, the number of Russians who expressed their willingness to join an environmental organization is only $12 \%$; although this number has increased fourfold since 2014, nevertheless, according to the Ministry of Justice, in recent years the number of environmental organizations themselves has been steadily decreasing: in 2018, there were 1,500 of them, compared to 2,100 in 2013 and 1,900 in 2016 [4].

In this regard, it is particularly important to understand the scale and significance of environmental problems not only by narrow specialists and representatives of a particular field of scientific research, but also by society as a whole. In particular, E.P. Semenyuk shares the ecologization of public consciousness and the ecologization of social practice as interrelated, but not identical concepts.

For example, the greening of economic consciousness can be quite successful (convincing) in theory. Society often exerts social and political pressure on businesses to make them more responsible in protecting the environment. [9] However, in terms of social practice, it is incomparably more difficult to convince entrepreneurs in reality to be guided by the principles of ecological economics (rather than market economics).

Thus, at present, against the background of the general awareness of the society of a serious threat to environmental safety, there is a problem of the readiness of the population to show real activity in this area. Society needs a sustained awareness of the scale of the environmental crisis. A particularly important part of the population in the framework of this problem is young people.

According to Margaret Mead, young people are gradually moving towards a rejection of the focus on traditions and the use of the life experience of older generations to achieve success, and influence, in turn, older generations [5].

Countercultural tendencies in the youth environment are also noted by Theodor Rozzak, speaking about the phenomenon of youth revolt, born on the basis of a youth challenge to traditional culture based on rationalism [8].

Thus, conceptually justifying changes in the nature of social statuses and roles, scientists note the contradictory and active nature of the influence of modern youth on social changes. 
This problem can be considered in the framework of K. Manheim approach.

According to his concept, young people act as a generation in the appropriate historical and social space, which is able to mobilize hidden resources and increase the viability of society.

Being one of the social reserves, the younger generation activates its activities when there is a public need. At the same time, Manheim, unlike Marx, speaks about the absence of any class traits in young people, considering them simply a potency that responds positively to an external challenge.

According to Manheim, the prerogative of a dynamic society is, unlike traditional society, not to suppress the potential of young people, but to mobilize and integrate it. Thus, the society should respond competently to the emergence of qualitatively new circumstances and be able to use the potential of young people in solving social problems. [3, p.440-441] Also, according to E. Durkheim, the young generation should not be brought up according to too outdated views or too premature (in this case, it does not belong to its time and exists in abnormal living conditions) [1, p.2].

Thus, the importance of greening the consciousness and social practice of young people becomes clear.

On the one hand, experts note that most of the participants of environmental organizations are young people.

On the other hand, the effectiveness of the use of information technologies in the process of activating and regulating the orientation of social practice is indicated [6].

It is also possible to identify a number of features that characterize Internet technologies as a tool that contributes to increasing the activity of the population, and especially young people, in a particular field of activity.

In particular, it is indicated that receiving information on the Internet in any form is perceived more positively by the younger generation than informing through other sources of information: communication has a more intimate character, transfers relationships to a new level of loyalty, the possibility of active participation in political struggle, due to a significant decrease in the influence of censorship, the absence of geographical boundaries within the Internet community, the flow of communication in real time, the ability always to be part of the community, notify about your location, upload ideas to the network, not to store any significant amounts of information in memory.
Experts also call one of the characteristics of Internet communities high political activity of those members who do not show such in real life [6]. Finally, the prevalence and relative autonomy of Internet communities made them an ideal environment for the emergence of protest moods, which, according to the above approaches, are characteristic of the younger generation [5].

Thus, the process of greening society, and especially young people, can be optimized through the active use of information, in particular, digital technologies.

\section{EDUCATION AS A MECHANISM FOR USING MODERN TECHNOLOGIES IN THE DIRECTION OF GREENING OF SOCIETY}

At the same time, it is necessary to pay attention to the aspects related to education.

Environmental education is a continuous process of training, education and personal development aimed at forming a system of scientific and practical knowledge and skills, value orientations, behavior and activities that ensure a responsible attitude to the environment and health. Environmental education is an integral part of the overall human culture, so the quality of the use of environmental knowledge ultimately depends on the harmonization of the relationship between the environment and humans.

Taking it into consideration, it is possible to become a qualified specialist in any field of knowledge in the XXI century only if you have a good command of modern technologies, since the professional activity of specialists increasingly depends on their ability to effectively extract, use and present information qualitatively.

At the same time, they contribute to the improving of the effectiveness of training, such as increasing the activity of the student, concentrating the student's attention during training, his/her additional interest directly in the way of obtaining knowledge and individualizing the learning process. The research conducted by the author Korolkova L.N. allowed to reveal the dynamics of students' attitude to computerization of teaching and talk about the increasing of students' motivation for classes, as well as contributing to more productive assimilation of knowledge, skills and abilities.

The implementation of the computerization model of teaching made it possible to more fully meet the requirements of the following pedagogical principles: 
Table 1. Factors that determine the need to use modern information technologies in the direction of deepening the greening of society

\begin{tabular}{|c|c|c|}
\hline No. & Factor & Purpose of use \\
\hline 1. & $\begin{array}{l}\text { The importance of the social aspect in the environmental protection, } \\
\text { which implies an appropriate perception of environmental problems } \\
\text { by all members of society. }\end{array}$ & $\begin{array}{l}\text { The formation of an appropriate attitude } \\
\text { to the environmental problems among all } \\
\text { members of society. }\end{array}$ \\
\hline 2. & $\begin{array}{l}\text { The need to adjust the models of environmental policy used in Russia } \\
\text { and neighboring countries, due to the lack of real levers of } \\
\text { environmental organizations to influence the elimination of } \\
\text { environmental threats and the solution of environmental problems. }\end{array}$ & $\begin{array}{l}\text { The formation of real levers for } \\
\text { environmental organizations to influence } \\
\text { the elimination of environmental threats } \\
\text { and the solution of environmental } \\
\text { problems. }\end{array}$ \\
\hline 3. & $\begin{array}{l}\text { The lack of activity of the society at this stage of development in the } \\
\text { direction of influencing social institutions in order to develop and } \\
\text { implement a system of measures to protect the environment. }\end{array}$ & $\begin{array}{l}\text { The increasing of the activity of the } \\
\text { population in the direction of influencing } \\
\text { social institutions in order to develop and } \\
\text { implement a system of measures to } \\
\text { protect the environment. }\end{array}$ \\
\hline 4. & $\begin{array}{l}\text { The expediency of measures to activate, first of all, young people in } \\
\text { the process of increasing the activity of the population to protect the } \\
\text { environment. }\end{array}$ & $\begin{array}{l}\text { The improving of the environmental } \\
\text { practices of the most mobile population } \\
\text { group. }\end{array}$ \\
\hline 5. & $\begin{array}{l}\text { A more positive perception of the population, and, above all, the } \\
\text { younger generation, of information disseminated through modern } \\
\text { information technologies, and primarily in digital format. }\end{array}$ & $\begin{array}{l}\text { The increasing of the activity of the } \\
\text { population in the direction of influencing } \\
\text { social institutions in order to develop and } \\
\text { implement a system of measures to } \\
\text { protect the environment. }\end{array}$ \\
\hline 6. & $\begin{array}{l}\text { The feasibility of using the potential of the education system in the } \\
\text { field of modern information technologies in order to develop and } \\
\text { implement a system of measures to protect the environment. }\end{array}$ & $\begin{array}{l}\text { The improving of the environmental } \\
\text { practices of the most mobile population } \\
\text { group. }\end{array}$ \\
\hline
\end{tabular}

- the principle of accessibility and affordability

- the principle of consciousness and activity of students,

- the principle of continuity, consistency and systematicity,

- the principle of visibility.

The results of the experiment showed the advantages of using information technologies in the teaching process over the use of traditional methods of teaching these disciplines [2, p.118].

Within the framework of this problem, the concentration of intellectual resources of the young generation in the system of relations that develops in the world wide web can be used for the purpose of greening youth as the main part of society. The younger generation almost universally interacts in this format for a significant part of the time of day, and most positively perceives the information transmitted in the appropriate quality through the Network.

\section{CONCLUSIONS}

Generalization of the above allows us to identify the factors that determine the need for the use of modern information technologies in the direction of deepening the greening of society (table 1).

Based on these points, we can talk about creating prerequisites for deepening the greening of society if the following measures are taken:

- in order to develop the environmental practices of the population, it is necessary to dramatically increase the amount of information related to ecology in Internet sources,

- the main tool for transmitting relevant information to the population should be modern information, including digital technologies. This aspect directly concerns the education system. The use of new 
information technologies will make it possible to translate trends in the greening of science into the education system,

- perhaps the state should work to adjust the regulatory framework for environmental organizations, which would increase the ability of such organizations to influence the process of developing and making appropriate policy decisions, as well as participate in the formation of mechanisms for involving the population in solving environmental problems.

Society needs to remember that in modern conditions of human activity, the urgency and importance of reducing environmental threats not only does not lose its relevance, but every year, due to technological and technical development, the growth of economic problems and the multiplication of needs, it increases its importance.

\section{REFERENCES}

[1] E. Durkheim, Sociology of education, Intor, 1996, 77 p. DOI: https://revolution.allbest.ru/sociology/00252029 2. $\underline{\mathrm{html}}$

[2] L.N. Korolkova, Pedagogical conditions of computerization of teaching electrotechnical disciplines to students of non-electrotechnical specialties: diss. can. ped. scences: 13.00.08., Stavropol, 2007, 147 p. Retrieved from: il. THE RSL OD, 61 07-13/2057 (In Russ.).

[3] K. Manheim, Diagnosis of Our Time, Jurist, 1994, 700 p. $\quad$ DOI: http://yakov.works/libr_min/13_m/an/heim3.html (In Russ.)

[4] E.V. Matveeva, Environmental organizations in the Post-Soviet States as a tool for solving environmental challenges (on the example of the Russian Federation and Ukraine), Bulletin of Tomsk State University 449 (2019) 88-92. DOI: 10.17223/15617793/449/11 UDC 329.7 (In Russ.).

[5] M. Mead, Culture and the world of childhood, Science, $1988, \quad 429$ p. DOI: http://base.dnsgb.com.ua/files/book/kultura-i-mirdetstva.pdf (In Russ.).

[6] S. Nosova, Methodological grounds for studying the society-network, Methodological foundations for the Study of society-Networks, Vestn. Tom, GOS, UN-TA 2 (2012) 53-56. DOI: https://cyberleninka.ru/article/n/metodologicheskie -osnovaniya-izucheniya-obschestva-seti

[7] Future policy scenarios are outlined in the UNEP "Global Environment Outlook GEO-3 report". Which of them is preferable for Russia, ECOS 3
(2003) 8-11. DOI: https://sov.opredelim.com/docs/138100/index2965.html (In Russ.).

[8] Th. Roszak, The Making of a Counter Culture: Reflections on the Technocratic Society and Its Youthful Opposition, N.Y., 1969, p. 380. DOI: https://ru.scribd.com/doc/68962275/The-Makingof-a-Counter-Culture-Theodore-Roszak

[9] E.P. Semenyuk, The role of informatics in the greening of society, NTI. Ser. 1 Organization and methodology of information work 1 (2012) 1-12. DOI: http://elibrary.ru/item.asp?id=17740660 (In Russ.).

[10] E.P. Semenyuk, Sustainable Development of society and informatics, NTI Ser. 1 Iss. 1 (2000) 1 11.

DOI:

http://lamb.viniti.ru/sid2/sid2free?sid2=J18341109 (In Russ.)

[11] The Earth Summit. The United Nations Conference on Environment and Development (UNCED), Introd. and commentary by Stanley P. Johnson. London: Graham and Trotman, 1992, 532 p. DOI: https://documents-ddsny.un.org/doc/UNDOC/GEN/N92/836/57/PDF/N9 283657.pdf?OpenElement 